\title{
Identification and characterization of genes related to cellulolytic activity in basidiomycetes
}

\author{
A.F.N. Volpini' ${ }^{1}$, T. Thomazine ${ }^{1}$, S.H. Umeo ${ }^{1}$, G.A. Pereira ${ }^{2}$, G.A. Linde ${ }^{1}$, \\ J.S. Valle ${ }^{1}$, N.B. Colauto ${ }^{1}$, F.G. Barcellos ${ }^{2}$ and S.G.H. Souza ${ }^{1}$ \\ ${ }^{1}$ Programa de Pós-Graduação em Biotecnologia Aplicada à Agricultura, \\ Universidade Paranaense, Umuarama, PR, Brasil \\ ${ }^{2}$ Departamento de Biologia Geral, Universidade Estadual de Londrina, \\ Londrina, PR, Brasil \\ Corresponding author: J.S. Valle \\ E-mail: jsvalle@unipar.br
}

Genet. Mol. Res. 15 (3): gmr.15038722

Received April, 25, 2016

Accepted June 2, 2016

Published September 16, 2016

DOI http://dx.doi.org/10.4238/gmr.15038722

Copyright (C 2016 The Authors. This is an open-access article distributed under the terms of the Creative Commons Attribution ShareAlike (CC BY-SA) 4.0 License.

\begin{abstract}
Enzymes produced by basidiomycetes that are involved in the cellulose degradation process, and their respective codifying genes, must be identified to facilitate the development of novel biotechnological strategies and applications in the agro-industry. The objective of this study was to identify prospective cellulase-producing genes and characterize their cellulolytic activity, in order to elucidate the potential biotechnological applications (with respect to vegetal residues) of basidiomycetes. The basidiomycete strains Lentinula edodes U8-1, Lentinus crinitus U9-1, and Schizophyllum commune U6-7 were analyzed in this study. The cellulolytic activities of these fungi were evaluated based on the halo formation in carboxymethyl cellulose culture medium after dyeing with Congo red. The presence of cellulase-codifying genes (cel7A, cel6B, cel3A, and egl) in these fungal strains was also evaluated. L. edodes and $S$. commune
\end{abstract}


presented the highest cellulolytic halo to mycelial growth radius ratio, followed by $L$. crinitus. Four genes were amplified in the $L$. edodes strain, whereas three and one genes were isolated from $L$. crinitus and $S$. commune, respectively. The cel6B gene ( $L$. edodes) presented the conserved domain glyco_hydro_6 and characterized as cellobiohydrolase gene. The results of this study contribute to the existing knowledge on cellulases in basidiomycetes, and serve as a basis for future studies on the expression of these genes and the characterization of the catalytic activity of these enzymes. This allows for better utilization of these fungi in degrading vegetal fibers from agro-industrial residues and in other biotechnological applications.

Key words: Basidiomycetes; Cellulase; Lentinula edodes; Lentinus crinitus; Schizophyllum commune

\section{INTRODUCTION}

Lignocellulose is the main component of plant biomass and the most abundant renewable organic resource in the world, with broad applications (at a relatively low cost) in agro-industry. However, the physical and chemical composition of lignocellulose is very complex; this allows lignocellulose to resist chemical and biological attacks, complicating its hydrolytic conversion into materials with a higher aggregated value.

Lignocellulose consists of cellulose, hemicellulose, and lignin. Cellulose is a fibrous, insoluble, and crystalline homopolysaccharide composed of linear chains of D-glucose linked by $\beta-1,4$ glycosidic bonds. The strong alignment of its chains and its structural stability confer cellulose with resistance to enzymatic attacks (Bayer et al., 1998). However, several fungi have been shown to promote enzymatic hydrolysis of cellulose through the action of an extracellular cellulolytic complex. Chief among these are basidiomycetes, which produce these enzymes to hydrolyze vegetable fibers.

Cellulolytic fungi produce an enzymatic system composed of three groups of enzymes: endoglucanase or endo- $\beta-1,4$ glucanase (E.C. 3.2.1.4), exoglucanase or exo-1,4$\beta$-glucanase (E.C. 3.2.1.91), and $\beta$-D-glucosidase (EC 3.2.1.21) (Song et al., 2008). Cellular hydrolysis occurs in oligosaccharides and glucose when there is complete synergy between these enzyme groups.

The system of regulatory genes that codify cellulolytic enzymes, such as cellulase (which is controlled at the transcriptional level), is complex and well-studied (GutiérrezRojas et al., 2015). The various genes coding for cellulase have already been sequenced in basidiomycetes such as Agaricus bisporus (Yagüe et al., 1996) and several Polyporales (Hori et al., 2013). Novel cellulolytic enzymes and their respective codifying genes in fungi must be identified to understand the multi-enzymatic degradation process, to develop new strategies for the utilization of vegetal residues, and to determine their potential biotechnological applications.

Therefore, the objective of this study was to identify prospective cellulase-producing genes in basidiomycetes and characterize their cellulolytic activity, to elucidate the potential biotechnological applications (with respect to vegetal residues) of basidiomycetes.

Genetics and Molecular Research 15 (3): gmr.15038722 


\section{MATERIAL AND METHODS}

\section{Biological material}

Three species of basidiomycetes, obtained from the Culture Collection of the Laboratory of Molecular Biology, Universidade Paranaense, were evaluated in this study: Lentinula edodes (Berk.) Pegler U8-1, Lentinus crinitus (L.) Fr. U9-1, and Schizophyllum commune Fr.U6-7. The strains were cultivated in potato dextrose agar (PDA; $39 \mathrm{~g} / \mathrm{L}$ ) at $28^{\circ} \pm$ $1{ }^{\circ} \mathrm{C}$ in the dark; these cultured strains were used to produce the inoculum.

\section{Cellulolytic activity}

The cellulolytic activity was determined as described previously by Jo et al. (2011), with some modifications. The mycelium was grown in culture medium containing $10 \mathrm{~g} / \mathrm{L}$ carboxymethyl cellulose, $5 \mathrm{~g} / \mathrm{L}$ peptone, $5 \mathrm{~g} / \mathrm{L}$ yeast extract, $5 \mathrm{~g} / \mathrm{L} \mathrm{K}_{2} \mathrm{HPO}_{4}, 1 \mathrm{~g} / \mathrm{L} \mathrm{NaCl}, 0.2 \mathrm{~g} / \mathrm{L}$ $\mathrm{MgSO}_{4} \cdot 7 \mathrm{H}_{2} \mathrm{O}, 0.6 \mathrm{~g} / \mathrm{L}\left(\mathrm{NH}_{4}\right)_{2} \mathrm{SO}_{4}$, and $15 \mathrm{~g} / \mathrm{L}$ agar. The culture medium, which was autoclaved at $121^{\circ} \mathrm{C}$ for $20 \mathrm{~min}$, was inoculated with a $5-\mathrm{mm}$ PDA disk containing mycelia, and incubated at $28^{\circ} \pm 1{ }^{\circ} \mathrm{C}$ for 7 days. Subsequently, $10 \mathrm{~mL}$ Congo red solution $(2 \mathrm{~g} / \mathrm{L}$; prepared with 0.1 $\mathrm{mM}$ Tris- $\mathrm{HCl}$ buffer at $\mathrm{pH} 8.0$ ) was added to the mycelium. The dye was discarded after 10 min and the dish was washed twice with a $1 \mathrm{M} \mathrm{NaCl}$ solution. The formation of a light-yellow halo in contrast with the red background indicates the production of cellulase. The thickness of the halo and the radial mycelial growth were measured by a pachymeter $( \pm 0.02 \mathrm{~mm})$ and the ratio between the halo thickness and the mycelial radius was calculated.

\section{DNA extraction}

The strains were grown in $100 \mathrm{~mL}$ liquid medium supplemented with $2 \%(\mathrm{~m} / \mathrm{v})$ malt extract at $28^{\circ} \pm 1^{\circ} \mathrm{C}$ for 7 days. The mycelial biomass was separated by filtration and washed twice with $30 \mathrm{~mL}$ ultrapure water. DNA was extracted using a method described by Raeder and Broda (1985). The mycelial biomass was transferred to a porcelain mortar, macerated with liquid nitrogen, mixed with $2.1 \mathrm{~mL} / \mathrm{g}$ extraction buffer ( $1 \mathrm{M}$ Tris-HCl, $\mathrm{pH} 8.0,5 \mathrm{M} \mathrm{NaCl}, 0.5 \mathrm{M}$ EDTA, $\mathrm{pH} 8.0$, and $10 \% \mathrm{SDS}$ ), and incubated at $65^{\circ} \mathrm{C}$ for $15 \mathrm{~min}$. The resulting lysate was extracted twice, once with phenol and again with a chloroform-isoamyl alcohol (24:1) mixture. After each extraction, the material was centrifuged at $15,200 \mathrm{~g}$ for $5 \mathrm{~min}$. The extracted DNA was precipitated with isopropanol, recovered by centrifugation ( $15200 \mathrm{~g}$ for $5 \mathrm{~min}$ ), washed twice with ethanol [once with 70\% ethanol (v/v) and again with $95 \%$ ethanol (v/v)], and centrifuged again (15200 $g$ for $15 \mathrm{~min}$ ). The obtained DNA was re-suspended in ultrapure water and stored at $-80^{\circ} \mathrm{C}$. The quality and quantity of extracted DNA were verified by electrophoresis on an agarose gel $(0.8 \%$; $\mathrm{m} / \mathrm{v}$ ), staining with ethidium bromide, and visualizing the gel with a UV transilluminator. The gel was then photographed by a photo image documenter (L-PIX - Molecular Imaging; Locus Biotecnologia, São Paulo, SP, Brazil). Lambda phage DNA was used as the molecular mass standard to quantify DNA (Life Technologies, Carlsbad, CA, USA).

\section{PCR amplification of cellulase genes}

The 50- $\mu \mathrm{L}$ PCR mix was composed of $0.15 \mathrm{mM}$ dNTPs, 1 X PCR buffer (20 mM Tris

Genetics and Molecular Research 15 (3): gmr.15038722 
base, $\mathrm{pH} 8.4$ and $50 \mathrm{mM} \mathrm{KCl}), 1.5 \mathrm{mM} \mathrm{MgSO}_{4}, 0.2 \mu \mathrm{M}$ primers, $2.0 \mathrm{U}$ Taq DNA polymerase, $25 \mathrm{ng}$ template DNA, and ultrapure water. DNA was amplified in a thermocycler (Mastercycler Gradient; Eppendorf, Hamburg, Germany) with an initial denaturation at $94^{\circ} \mathrm{C}$ for $4 \mathrm{~min} ; 35$ cycles of denaturation at $94^{\circ} \mathrm{C}$ for $1 \mathrm{~min}$, annealing at $50^{\circ}-58^{\circ} \mathrm{C}$ for $1 \mathrm{~min}$, extension at $72^{\circ} \mathrm{C}$ for $2 \mathrm{~min}$; and a final extension at $72^{\circ} \mathrm{C}$ for $7 \mathrm{~min}$.

The primers used were specific to endoglucanase and exoglucanase, with annealing in conserved regions of genes from the cellulase enzymatic complex. Primers specific for the egl gene of Agaricus bisporus (Morales and Thurston, 2003) were utilized for endoglucanases (EC 3.2.1.4): forward primer, 5'-CACCCGTCAGCGGAAGCGAT-3' and reverse primer, 5'-GGGCGCTGGTGCAGGGTAAG-3'. Primers specific for cel7A (forward, 5'-GAGCAGCA CCAGGGCCAGTTTTG-3' and reverse, 5'-TCTACGGCCCAGGTCTCACAGTCG-3') and cel6B (forward, 5'-GCGTTCCGAATCCAGCACCAA-3' and reverse, 5'-CGGCAACCCCTT CACTGGTTACG-3'), both from L. edodes (Lee et al., 2001), and cel3AC (forward, 5'-CAACCTGCGCTTCGGGCTCA-3' and reverse, 5'-AGGGCAGGGTTGGCATTCGC-3') (Chow et al., 1994) and cel3A (forward, 5'-CAACCTGCGCTTCGGGCTCA-3' and reverse, 5'-AGGGCAGGGTTGGCATTCGC-3') (Yagüe et al., 1996), both from A. bisporus, were utilized for exoglucanases (EC 3.2.1.91).

The amplified products were electrophoresed on a $0.8 \%$ agarose gel stained with ethidium bromide, using the Ladder $1 \mathrm{~kb}$ Plus marker (Life Technologies) as the molecular size standard. The electrophoresed gel was visualized and photographed under UV light by a photo image documentation equipment (Locus Biotecnologia).

\section{Sequencing of PCR products}

The amplified products were purified using the Purelink PCR Purification kit (Life Technologies) according to the manufacturer protocols, and sequenced by an ABI-Prism 3100 Genetic Analyzer (Applied Biosystems, Foster City, CA, USA) according to the manufacturer protocols. The nucleotide sequences were submitted to GenBank (NCBI).

\section{Identification of obtained gene sequences and presence of conserved protein domains}

The obtained sequences were analyzed for similarity with the gene sequences deposited in the GenBank database, utilizing the BLASTn program (NCBI). Conserved protein domains were identified by analyzing the similarity between our proteins and the protein sequences deposited in the GenBank database, utilizing BLASTx search tool (NCBI).

\section{RESULTS}

The results regarding the production of cellulolytic enzymes are summarized in Table 1. The ratio of the degradation halo thickness to the mycelial growth radius indicates the enzymatic activity. Fungi showing a higher ratio of degradation halo thickness to the mycelial growth radius show greater cellulolytic activity per millimeter of mycelium. In this study, this ratio varied from 0.30 to 2.20 , with $L$. edodes U8-1 and S. commune U6-7 showing the best cellulolytic activity (Table 1). 
Table 1. Mycelial growth radius and cellulolytic halo thickness.

\begin{tabular}{l|c|c|c|c}
\hline Fungus & Strain & Cellulolytic halo thickness $(\mathrm{mm})$ & Mycelial radius $(\mathrm{mm})$ & Ratio between halo thickness and mycelial radius \\
\hline Lentinula edodes & $\mathrm{U} 8-1$ & $11.75 \pm 1.07$ & $5.37 \pm 0.47$ & $2.20 \pm 0.35$ \\
\hline Lentinus crinitus & $\mathrm{U} 9-1$ & $7.17 \pm 1.44$ & $23.58 \pm 0.22$ & $0.30 \pm 0.06$ \\
\hline Schizophyllum commune & $\mathrm{U} 6-7$ & $7.51 \pm 0.95$ & $5.64 \pm 0.67$ & $1.33 \pm 0.56$ \\
\hline
\end{tabular}

Cellulase genes were amplified from all strains of fungus (Table 2). Four cellulase genes were amplified from $L$. edodes U8-1, whereas three and one genes were amplified from L. crinitus U9-1 and S. commune U6-7, respectively (Table 2).Two L. edodes U8-1 cel6B gene sequences were obtained from the amplification products and deposited in GenBank (NCBI) (Table 3). These sequences showed $100 \%$ similarity with $L$. edodes gene sequences previously deposited in GenBank. The cel6B gene identified in L. edodes U8-1 was characterized according to the presence of a conserved protein domain, by analyzing the similarity between the predicted protein sequence and the protein sequences previously deposited in GenBank, using the BLASTx algorithm (Table 4).

Table 2. PCR amplification of basidiomycete cellulase genes.

\begin{tabular}{l|l|l|l}
\hline Gene & Enzyme & Strain & Fungus \\
\hline cel7A & Exoglucanase & U8-1 & Lentinula edodes \\
\hline cel6B & Exoglucanase & U8-1 & Lentinula edodes \\
\hline cel3AC & Exoglucanase & U9-1 & Lentinus crinitus \\
\hline \multirow{2}{*}{ el3A } & Exoglucanase & U6-7 & Schizophyllum commune \\
& & $\mathrm{U} 8-1$ & Lentinula edodes \\
\cline { 3 - 4 } & & $\mathrm{U} 9-1$ & Lentinus crinitus \\
\cline { 2 - 4 } & & $\mathrm{U} 8-1$ & Lentinula edodes \\
\cline { 2 - 4 } & \multirow{2}{*}{ Egl } & $\mathrm{U} 9-1$ & Lentinus crinitus \\
\cline { 3 - 4 } & & &
\end{tabular}

Table 3. Identification of gene sequences obtained from PCR amplification of cel6B (cellulase), and their similarity to sequences deposited in the GenBank database (NCBI).

\begin{tabular}{l|c|c|l|l|c|c}
\hline Strain & Sequence size (bp) & GenBank accession No. & Description of identified gene, origin species* (GenBank accession No.) & Maximum identity (\%) & E-value \\
\hline Lentinula edodes U8-1 & 150 & KT447633 & Cellulase CEL6B (cel6B) mRNA, complete cds Lentinula edodes (AF411251.1) & 100 & $2 \mathrm{e}^{-69}$ \\
\hline Lentinula edodes U8-1 & 198 & KT447633 & Cellulase CEL6B (cel6B) mRNA, complete cds Lentinula edodes (AF411251.1) & 100 & $2 \mathrm{e}^{-95}$ \\
\hline
\end{tabular}
\begin{tabular}{|c|c|c|c|c|c|c|}
\hline Lentinula edodes U8-1 & 198 & KT447633 & Cellulase CEL6B (cel6B) mRNA, complete cds Lentinula edodes (AF411251.1) & 100 & $2 \mathrm{e}^{-95}$ \\
\hline
\end{tabular}

*Only those GenBank sequences with a similarity score $>90 \%$ with the obtained gene sequences were used in the analysis.

Table 4. Identification of conserved protein domains from gene sequences obtained by PCR amplifications of cel6B gene (cellulase), and their similarity to amino acid sequences deposited in the GenBank database (NCBI).

\begin{tabular}{|c|c|c|c|c|c|c|}
\hline Strain & $\begin{array}{c}\text { Sequence size } \\
\text { (bp) }\end{array}$ & $\begin{array}{c}\text { GenBank } \\
\text { accession No. }\end{array}$ & Description of protein, origin species*, (GenBank accession No.) & $\begin{array}{l}\text { Description of identified } \\
\text { preserved domain }\end{array}$ & $\begin{array}{c}\text { Maximum } \\
\text { identification (\%) }\end{array}$ & E-value \\
\hline Lentinula edodes U8-1 & 150 & KT447633 & \begin{tabular}{|l} 
Cellobiohydrolase Lentinula edodes (AAK28357.1) \\
\end{tabular} & Glyco_hydro_6 & 100 & $4 \mathrm{e}^{-26}$ \\
\hline Lentinula edodes U8-1 & 198 & KT447634 & \begin{tabular}{|l} 
Cellobiohydrolase Lentinula edodes (AAK28357.1) \\
\end{tabular} & Glyco_hydro_6 & 100 & $5 \mathrm{e}^{-36}$ \\
\hline
\end{tabular}

*Only those GenBank sequences with a similarity score $>80 \%$ with the obtained amino acid sequences were used in the analysis.

\section{DISCUSSION}

Basidiomycetes have a wide range of biotechnological applications (Umeo et al., 2015); these fungi are known to survive on several types of vegetal material and environments primarily because of their ability to utilize a number of natural carbon sources and degrade cellulose and other polysaccharides (Rytioja et al., 2014). The basidiomycetes strains analyzed in this study were confirmed to produce cellulases (Table 1).

Genetics and Molecular Research 15 (3): gmr.15038722 
L. edodes U8-1 showed a higher ratio of degradation halo thickness to mycelial growth radius, indicating its higher cellulolytic activity during the degradation of substratecontaining carboxymethyl cellulose. L. edodes, a white-rot fungi, produces ligninases that are used in paper bleaching and the biodegradation of xenobiotics. This fungus is also an excellent producer of endoglucanases, exoglucanases, and $\beta$-glycosidases. Pereira Júnior et al. (2003), who studied the activity of $L$. edodes cellulases, detected endoglucanase activity in liquid media containing carboxymethyl cellulose and microcrystalline cellulose, showing that the concentration as well as type of cellulose affected the enzymatic activity. Therefore, L. edodes has excellent cellulolytic potential, is able to degrade several carbon sources, and presents activities that are related to, and dependent on, the substrate composition.

The white-rot fungus $S$. commune U6-7, the second-highest producer of cellulase in this study (Table 1), can degrade all the components of the vegetal cell wall using a host of hemicellulose- and cellulose-degrading enzymes such as $\beta$-glycosidases and exoglucanases (Tsujiyama and Ueno, 2011). Additionally, it is reportedly an excellent lignin degrader (Rytioja et al., 2014). This species is considered as a model for degradation because of its capacity to produce a diverse set of enzymes that can degrade lignocellulosic substrates (Rytioja et al., 2014).

The L. crinitus U9-1 strain also showed significant cellulolytic activity (Table 1); however, it was less efficient (than L. edodes U8-1 and S. commune U6-7) in degrading carboxymethyl cellulose. Atri and Sharma (2012) reported that all types of Lentinus spp cultured in media containing carboxymethyl cellulose presented cellulolytic activity. However, no other studies have attempted to analyze the cellulase production capacity of $L$. crinitus so far.

Several of the cellulase-codifying genes detected in the strains analyzed in our study (Table 2), such as cel7A and cel6B, have already been reported in other basidiomycetes such as Phanerochaete chrysosporium (Muñoz et al., 2001) and Cropinopsis cinerea (Liu et al., 2009), respectively. Similarly, Ishihara et al. (2005) noted that the genes cel3A and egl (endoglucanase gene) identified (in their study) in Polyporus arcularius and L. edodes U8-1, respectively had been previously identified in other species of basidiomycetes such as Ustilago maydis (Zheng and Ding, 2013).

In this study, only the gene sequence of cel6B of L. edodes U8-1 was analyzed; additionally, its characteristic cellulase protein domains, such as the glyco hydro 6 domain (Table 4), which was representative of the cellulase-expressing functionality of this gene, were identified. This gene was previously isolated from L. edodes by Taipakova et al. (2011), and the sequence of amino acids codified by the gene was highly homologous to the protein sequences of the glycosyl hydrolase family (No. 6). Lee et al. (2001) reported that the gene cel6B from L. edodes contains 444 amino acids and has a typical catalytic domain that can be classified as glycosyl hydrolase family 6 member ( $c b h$ II-1). Cellulolytic enzymes were classified into at least 120 protein families, and they constitute one of the largest groups in the modern structural classification of glycosyl hydrolases. Bhat and Bhat (1997), when analyzing cellulase catalytic domains, identified a considerable variation among cellulases and, by analyzing the hydrophobic groups of catalytic domains, classified them into structurally related families, where in the members of the same family presented the same protein configuration and stereo selectivity, and shared the same hydrolytic mechanism.

Family 6 of glycosyl hydrolases is mainly composed of proteins produced by cellulolytic bacteria and fungi (Liu et al., 2009). This family is composed of endoglucanases and cellobiohydrolases, and its members can vary according to their activity profiles. Endoglucanases and cellobiohydrolases present a distorted $\beta / \alpha$-barrel; however, cellobiohydrolases contain an

Genetics and Molecular Research 15 (3): gmr.15038722 
active site enclosed by two loops that form a tunnel whereas endoglucanases have a single loop with their active site being located within a gap (Liu et al., 2009).

The results of this study contribute to the existing knowledge on cellulases in basidiomycetes, and serve as a basis for future studies on the expression of these genes, and characterization of the catalytic activity of these enzymes. This allows for better utilization of these fungi in degrading vegetal fibers from agro-industrial residues and in other biotechnological applications.

\section{Conflicts of interest}

The authors declare no conflict of interest.

\section{ACKNOWLEDGMENTS}

Research supported by a grant provided by Coordenação de Aperfeiçoamento de Pessoal de Nível Superior (CAPES), Universidade Paranaense, and the Postgraduate Program of Biotechnology Applied to Agriculture.

\section{REFERENCES}

Atri NS and Sharma SK (2012). Qualitative estimation of cellulases and lignin modifying enzymes in five wild Lentinus species selected from North West India. Acad. J. Plant Sci. 3: 105-109.

Bayer EA, Chanzy H, Lamed R and Shoham Y (1998). Cellulose, cellulases and cellulosomes. Curr. Opin. Struct. Biol. 8: 548-557. http://dx.doi.org/10.1016/S0959-440X(98)80143-7

Bhat MK and Bhat S (1997). Cellulose degrading enzymes and their potential industrial applications. Biotechnol. Adv. 15: 583-620. http://dx.doi.org/10.1016/S0734-9750(97)00006-2

Chow CM, Yagüe E, Raguz S, Wood DA, et al. (1994). The cel3 gene of Agaricus bisporus codes for a modular cellulase and is transcriptionally regulated by the carbon source. Appl. Environ. Microbiol. 60: 2779-2785.

Gutiérrez-Rojas I, Moreno-Sarmiento N and Montoya D (2015). Mechanisms and regulation of enzymatic hydrolysis of cellulose in filamentous fungi: classical cases and new models. Rev. Iberoam. Micol. 32: 1-12.

Hori C, Gaskell J, Igarashi K, Samejima M, et al. (2013). Genomewide analysis of polysaccharides degrading enzymes in 11 white- and brown-rot Polyporales provides insight into mechanisms of wood decay. Mycologia 105: 1412-1427. http://dx.doi.org/10.3852/13-072

Ishihara H, Aimi T, Takahashi K and Kitamoto Y (2005). Heterologous expression and characterization of the endocellulase encoding gene cel $3 \mathrm{~A}$ from the basidiomycete Polyporus arcularius. Mycoscience 46: 154-161. http:// dx.doi.org/10.1007/S10267-005-0225-0

Jo WS, Park HN, Cho DH, Yoo YB, et al. (2011). Optimal media conditions for the detection of extracellular cellulose activity in Ganoderma neo-japonicum. Mycobiology 39: 129-132. http://dx.doi.org/10.4489/MYCO.2011.39.2.129

Lee CC, Wong DW and Robertson GH (2001). Cloning and characterization of two cellulase genes from Lentinula edodes. FEMS Microbiol. Lett. 205: 355-360. http://dx.doi.org/10.1111/j.1574-6968.2001.tb10972.x

Liu Y, Igarashi K, Kaneko S, Tonozuka T, et al. (2009). Characterization of glycoside hydrolase family 6 enzymes from Coprinopsis cinerea. Biosci. Biotechnol. Biochem. 73: 1432-1434. http://dx.doi.org/10.1271/bbb.80888

Morales P and Thurston CF (2003). Efficient isolation of genes differentially expressed on cellulose by suppression subtractive hybridization in Agaricus bisporus. Mycol. Res. 107: 401-407. http://dx.doi.org/10.1017/S0953756203007366

Muñoz IG, Ubhayasekera W, Henriksson H, Szabó I, et al. (2001). Family 7 cellobiohydrolases from Phanerochaete chrysosporium: crystal structure of the catalytic module of Cel7D (CBH58) at 1.32 A resolution and homology models of the isozymes. J. Mol. Biol. 314: 1097-1111. http://dx.doi.org/10.1006/jmbi.2000.5180

Pereira Júnior JAS, Correia MJ and Oliveira NT (2003). Cellulase activity of a Lentinula edodes (Berk.) Pegl. strain grown in media containing carboximetilcellulose or microcrystalline cellulose. Braz. Arch. Biol. Technol. 46: 333-337. http://dx.doi.org/10.1590/S1516-89132003000300004

Raeder U and Broda P (1985). Rapid preparation of DNA from filamentous fungi. Lett. Appl. Microbiol. 1: 17-20. http://

Genetics and Molecular Research 15 (3): gmr.15038722 
dx.doi.org/10.1111/j.1472-765X.1985.tb01479.x

Rytioja J, Hildén K, Yuzon J, Hatakka A, et al. (2014). Plant-polysaccharide-degrading enzymes from Basidiomycetes. Microbiol. Mol. Biol. Rev. 78: 614-649. http://dx.doi.org/10.1128/MMBR.00035-14

Song BC, Kim KY, Yoon JJ, Sim SH, et al. (2008). Functional analysis of a gene encoding endoglucanase that belongs to glycosyl hydrolase family 12 from the brown-rot basidiomycete Fomitopsis palustris. J. Microbiol. Biotechnol. 18: 404-409.

Taipakova SM, Stanbekova G, Ischenko A, Saparbayerv M, et al. (2011). Cloning and expression of Lentinula edodes cellobiohydrolase CEL6B gene in E. coli. Int. J. Biol. Chem. 1: 19-26.

Tsujiyama S and Ueno H (2011). Production of cellulolytic enzymes containing cinnamic acid esterase from Schizophyllum commune. J. Gen. Appl. Microbiol. 57: 309-317. http://dx.doi.org/10.2323/jgam.57.309

Umeo SH, Souza GPN, Rapachi PM, Garcia DM, et al. (2015). Screening of basidiomycetes in submerged cultivation based on antioxidant activity. Genet. Mol. Res. 14: 9907-9914. http://dx.doi.org/10.4238/2015.August.19.25

Yagüe E, Chow CM, Challen MP and Thurston CF (1996). Correlation of exons with functional domains and folding regions in a cellulase from Agaricus bisporus. Curr. Genet. 30: 56-61. http://dx.doi.org/10.1007/s002940050100

Zheng F and Ding S (2013). Processivity and enzymatic mode of a glycoside hydrolase family 5 endoglucanase from Volvariella volvacea. Appl. Environ. Microbiol. 79: 989-996. http://dx.doi.org/10.1128/AEM.02725-12

Genetics and Molecular Research 15 (3): gmr.15038722 